\title{
Prototype "Pengamanan Ganda" pesan rahasia dengan menggunakan teknik Steganografi metode LSB dan Kriptografi metode Vigenere Cipher
}

\author{
Agung Wibowo \\ Universitas Muhammadiyah Tangerang / Fakultas Teknik, \\ Program Studi Informatika \\ Jl. Perintis Kemerdekaan 1/33 Cikokol Kota Tangerang TLP. 55793251, 55772949, 55793802, 55736926 \\ e-mail: agungismyname @gmail.com
}

\begin{abstract}
ABSTRAK
Saat ini teknologi informasi sudah sangat berkembang menjadi salah satu media yang paling populer didunia. dengan semakin berkembangnya teknologi informasi semakin berkembang pula tindak penyalahgunaan informasi yang bukan haknya. Maka dari itu perkembangan teknologi informasi harus juga dibarengi dengan perkembangan pengaman informasi seperti pesan rahasia. Salah satu cara pengamanan data pesan dapat dilakukan dengan kombinasi Teknik keamanan kriptografi dan steganografi. Tujuannya adalah untuk merahasiakan sebuah pesan. proses kombinasi kriptografi dan steganografi diyakini sebagai cara ampuh untuk melindungi pesan yang dikirim, serta sekaligus menghindari pesan tersebut dari kecurigaan.
\end{abstract}

Kata Kunci : Kriptografi, Steganografi, Vigenere Cipher, Least Significan Bit (LSB), Pesan rahasia.

\section{ABSTRACT}

Today information technology has growing into one of the world's most popular media. with the development of information technology is growing also acts misuse of information that is not right. then from development of information technology should also be coupled with the development of information security such as secret message. One way of securing data messages can be done with a combination of cryptography and steganography security techniques. The goal is to keep a message. the combination of cryptography and steganography believed to be a powerful way to protect messages sent and simultaneously avoid the message from suspicion.

Keyword : cryptography, steganography, Vigenere Cipher, Least Significan Bit (LSB), Secret message.

\section{PENDAHULUAN}

Saat ini perkembangan teknologi informasi dan komunikasi yang begitu pesat memungkinkan manusia berkomunikasi dan saling bertukar informasi secara jarak jauh, khususnya melalui media internet bukan merupakan suatu kendala lagi dalam melakukan komunikasi dan pertukaran data. Seiring dengan hal tersebut, tuntutan akan keamanan terhadap kerahasiaan informasi yang saling dikirimkan tersebut semakin meningkat. Penulis akan melakukan pengembangan terhadap pengamanan ganda pada pesan rahasia yang berupa text dengan menggunakan teknik Steganografi metode LSB (Least Significant Bit) dan teknik Kriptografi metode Vigenere Cipher. Pengamanan informasi dapat dilakukan dengan cara menyembunyikan informasi sebenarnya kedalam suatu media tertentu yang disebut dengan istilah Steganografi, atau mengacak informasi sebenarnya menjadi informasi yang tidak dapat dibaca dengan cara biasa yang disebut Kriptografi. Secara khusus kedua cara atau teknik tersebut adalah dua hal yang berbeda. Namun demikian kedua teknik tersebut 
memiliki tujuan yang sama yakni untuk mengamankan informasi.

\section{DASAR TEORI}

\section{A. STEGANOGRAFI}

Steganografi adalah seni dan ilmu menulis pesan tersembunyi atau menyembunyikan pesan dengan suatu cara sehingga selain si pengirim dan si penerima, tidak ada seorangpun yang mengetahui atau menyadari bahwa ada suatu pesan rahasia [22]

Steganografi memanfaatkan media digital untuk menyisipkan pesan rahasia melalui kode biner pada media digital tersebut, seperti: gambar, audio, video, text atau file biner.

Dalam prakteknya, sebenarnya pesan yang disembunyikan akan membuat perubahan tipis terhadap data digital yang disisipinya. namun karena perubahan itu sulit dilihat dengan mata, maka data tersebut tidak akan menarik perhatian dari orang yang tidak berhak untuk membaca pesan tersebut.

\section{B. LSB (LEAST SIGNIFICANT BIT)}

Metode steganografi sedemikian rupa dalam menyembunyikan isi suatu data di dalam suatu sampul media atau data digital lain yang tidak dapat diduga oleh orang biasa sehingga tidak menimbulkan kecurigaan kepada orang yang melihatnya.

Dalam membuat steganografi ada dua kriteria yang harus diperhatikan ${ }^{[12]}$, yaitu:

1. Fidelity. Mutu citra penampung tidak jauh berubah. Setelah penambahan data rahasia, citra hasil steganografi masih terlihat dengan baik. pihak ketiga tidak mengetahui kalau di dalam citra tersebut terdapat data rahasia.

2. Recovery. Data yang disembunyikan harus dapat diungkapkan kembali (recovery). karena tujuan steganografi adalah penyembunyian pesan, maka sewaktu-waktu pesan rahasia didalam citra penampung harus dapat diambil kembali untuk digunakan lebih lanjut

berikut adalah ilustrasi dasar dari konsep steganografi metode LSB (Least Significant Bit).

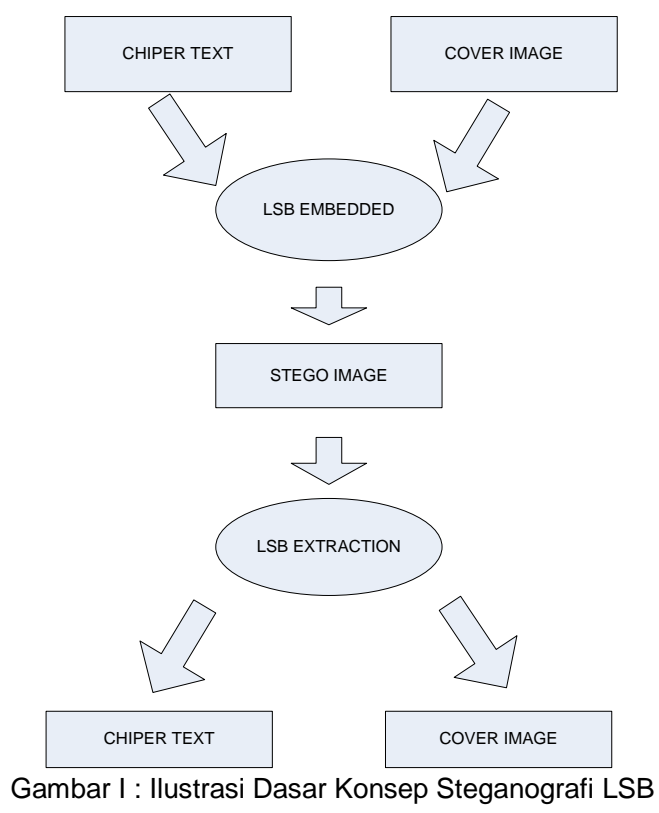


penyembunyian data dilakukan dengan mengganti bit-bit data di dalam segmen gambar dengan bit-bit data rahasia. Metode yang paling sederhana adalah metode modifikasi LSB (Least Significant Bit

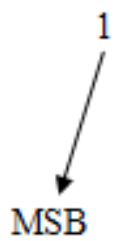

Metode Least Significant Bit (LSB) adalah
metode yang digunakan untuk menyembunyikan pesan dengan cara menyisipkannya pada bit rendah atau bit yang paling kanan (LSB) pada data piksel yang menyusun file tersebut. Pada citra bitmap 24 bit, setiap piksel (titik) pada citra tersebut terdiri dari tiga susunan warna, yaitu merah, hijau dan biru (RGB) yang masing-masing disusun oleh bilangan 8 bit (byte) dari 0 sampai 255 atau dengan format biner 00000000 sampai 11111111 . Dengan demikian, pada setiap piksel citra bitmap 24 bit kita dapat menyisipkan 3 bit data.

\section{KRIPTOGRAFI}

Kriptografi adalah seni dan ilmu untuk menulis rahasia "The Art of Secreet Writing". Tujuannya agar pesan tidak dapat dibaca dengan mudah. Proses yang dilakukan untuk mengamankan sebuah pesan (plaintext) menjadi pesan yang tersembunyi (ciphertext) disebut dengan enkripsi (encryption).

Pada dasarnya komponen kriptografi terdiri dari beberapa kompenen, seperti:

1. Enkripsi: merupakan hal yang sangat penting dalam kriptografi, merupakan cara pengamanan data yang dikirimkan sehingga terjaga kerahasiaannya. pesan asli disebut plaintext, yang diubah menjadi kode kode yang sulit dimengerti.

2. Deskripsi : merupakan kebalikan dari enkripsi. pesan yang telah di enkripsi dikembalikan ke bentuk asalnya.
Modification). Pada susunan bit di dalam sebuah byte ( 1 byte $=8$ bit), ada bit yang paling pertama (most significant bit atau MSB) dan bit yang paling terakir(least significant bit atau LSB).

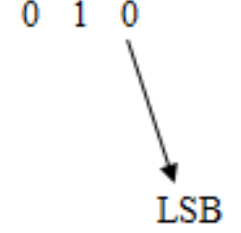

3. Kunci: kunci yang dipakai untuk melakukan enkripsi dan denkripsi.

4. Chiphertext: merupakan suatu pesan yang telah melalui proses enkripsi. pesan yang ada pada text-kode ini tidak bisa dibaca karena berupa karakter-karakter yang tidk mempunyai makna.

5. Plaintext: seding disebut dengan cleartext. text asli atau text biasa ini merupakan pesan yang ditulis atau diketik yang memiliki makna.

\section{VIGENERE CIPHER}

Ide dasarnya pengembangannya adalah menggunakan kode Caesar tetapi Jika pada Caesar Cipher setiap huruf digeser dengan besar geseran yang sama, maka pada Vigènere Cipher setiap huruf digeser dengan besar yang berbeda sesuai dengan kuncinya.

Kunci pada kriptografi Vigènere Cipher adalah sebuah kata bukan sebuah huruf. Kata kunci ini akan dibuat berulang sepanjang plaintext, sehingga jumlah huruf pada kunci akan sama dengan jumlah huruf pada plaintext. Pergeseran setiap huruf pada plaintext akan ditentukan oleh huruf pada kunci yang mempunyai posisi yang sama dengan huruf pada plaintext.

Vigènere Cipher menggunakan Bujursangkar Vigènere (tabula recta) untuk melakukan enkripsi dan dekripi. Seperti gambar dibawah ini: 


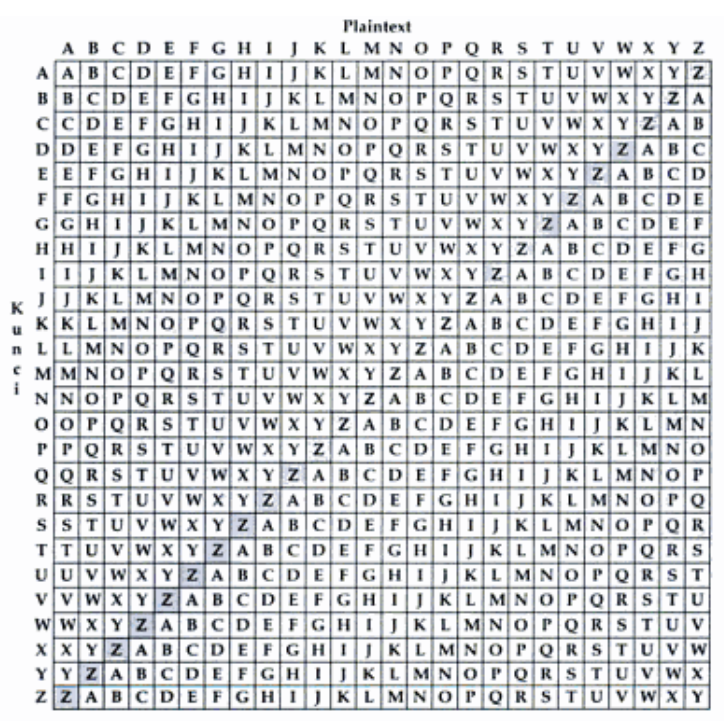

Tabel I : Bujursangkar Vigènere (tabula recta)

Kolom paling kiri dari bujursangkar menyatakan huruf-huruf kunci, sedangkan baris paling atas menyatakan huruf-huruf plaintext. Setiap baris di dalam bujursangkar menyatakan huruf-huruf ciphertert yang diperoleh dengan Caesar cipher, yang mana jumlah pergeseran huruf plaintext ditentukan nilai numerik huruf kunci tersebut (yaitu, $a=0$, $b=1, c=2, \ldots, z=25)$. Sebagai contoh, huruf kunci c (=2) menyatakan huruf-huruf plaintext digeser sejauh 2 huruf ke kanan (dari susunan alfabetnya), sehingga huruf-huruf ciphertext pada baris $\mathrm{c}$ adalah:

Algoritma enkripsi vigenere cipher :

$$
\mathrm{Ci}=(\mathrm{Pi}+\mathrm{Ki}) \bmod 26
$$

Algoritma dekripsi vigenere cipher :

$$
\mathrm{Pi}=(\mathrm{Ci}-\mathrm{Ki}) \bmod 26
$$

\section{Dimana :}

$\mathrm{Ci}=$ nilai desimal karakter

ciphertext ke-i

$\mathrm{Pi}=$ nilai desimal karakter plaintext ke-i

$\mathrm{Ki}=$ nilai desimal karakter kunci kei.

Sebagai contoh jika plaintext adalah THEBEAUTYANDTHEBEAST dan kunci adalah $A B C$ maka proses enkripsi yang terjadi adalah sebagai berikut:

\section{Plaintext : THEBEAUTYANDTHEBEAST Kunci ABCABCABCABCABCABCAB Chipertext : TIGBFCUUAAOFTIGBFCSU}

Pada contoh di atas kata kunci $A B C$ diulang sedemikian rupa hingga panjang kunci sama dengan panjang plainteksnya. Kemudian setelah panjang kunci sama dengan panjang plainteks, proses enkripsi dilakukan dengan melakukan menggeser setiap huruf pada plainteks sesuai dengan huruf kunci yang bersesuaian dengan huruf plainteks tersebut. Pada contoh di atas plainteks huruf pertama adalah $\mathrm{T}$ akan dilakukan pergeseran huruf dengan kunci $\mathrm{Ki}=0$ (kunci huruf pertama adalah $\mathrm{A}$ yang memiliki $\mathrm{Ki}=0$ ) menjadi $\mathrm{T}$. Huruf kedua pada plainteks adalah $\mathrm{H}$ akan dilakukan pergeseran huruf dengan kunci $\mathrm{Ki}=1$ (kunci huruf kedua adalah $\mathrm{B}$ yang memiliki $\mathrm{Ki}=1$ ) menjadi I. Begitu seterusnya dilakukan pergeseran sesuai dengan kunci pada tiap huruf hingga semua plainteks telah terenkripsi menjadi ciphertext.

E. TINJAUAN STUDI 
Tinjauan studi yang dijadikan acuan dalam melakukan penelitian tesis ini mengacu pada

\begin{tabular}{|c|c|c|}
\hline Penulis & Judul Penelitian & Metode \\
\hline $\begin{array}{l}\text { [Sulidar } \\
\text { 2009] }\end{array}$ & $\begin{array}{c}\text { Implementasi } \\
\text { algoritma } \\
\text { Kriptografi DES } \\
\text { dan Watermark } \\
\text { dengan metode } \\
\text { LSB pada data } \\
\text { citra }\end{array}$ & $\begin{array}{c}\text { Penelitian } \\
\text { pengamanan ganda } \\
\text { pada pesan rahasia } \\
\text { yang berupa text } \\
\text { dengan } \\
\text { menggunakan teknik } \\
\text { Steganografi metode } \\
\text { LSB dengan } \\
\text { Algoritma Kriptografi } \\
\text { DES (Data } \\
\text { Encryption } \\
\text { Standard) }\end{array}$ \\
\hline $\begin{array}{l}\text { [B.Raja } \\
\text { 2010] }\end{array}$ & $\begin{array}{l}\text { Novel Skema } \\
\text { Keamanan } \\
\text { Informasi } \\
\text { menggunakan } \\
\text { Cryptic- } \\
\text { Steganografi }\end{array}$ & $\begin{array}{c}\text { Kriptografi yang } \\
\text { digunakan MD-5 } \\
\text { Algorithm untuk } \\
\text { mengenkripsi pesan } \\
\text { dan pada pesan } \\
\text { tersembunyi } \\
\text { Steganografi } \\
\text { Discrete Cosine } \\
\text { Transform (DCT) }\end{array}$ \\
\hline $\begin{array}{l}\text { [Esti } \\
2010] .\end{array}$ & $\begin{array}{c}\text { Kombinasi } \\
\text { Kriptografi dengan } \\
\text { Hill Cipher dan } \\
\text { Steganografi } \\
\text { dengan LSB untuk } \\
\text { keamanan data } \\
\text { teks }\end{array}$ & $\begin{array}{c}\text { Penelitian } \\
\text { pengamanan ganda } \\
\text { pada pesan rahasia } \\
\text { yang berupa text } \\
\text { dengan } \\
\text { menggunakan teknik } \\
\text { Steganografi metode } \\
\text { LSB dengan } \\
\text { Algoritma Kriptografi } \\
\text { Hill Cipher }\end{array}$ \\
\hline $\begin{array}{l}\text { [Shrikant } \\
2010]\end{array}$ & $\begin{array}{c}\text { Implementasi } \\
\text { Steganografi } \\
\text { dengan Metode } \\
\text { Bit-Plane } \\
\text { Complexity } \\
\text { Segmentation } \\
\text { (BPCS) untuk } \\
\text { Dokumen Citra } \\
\text { Terkompresi }\end{array}$ & $\begin{array}{l}\text { Pada penelitian ini } \\
\text { dibahas mengenai } \\
\text { steganografi dengan } \\
\text { metode Bit-Plane } \\
\text { Complexity } \\
\text { Segmentation } \\
\text { dengan media citra } \\
\text { terkompresi. metode } \\
\text { BPCS ini }\end{array}$ \\
\hline
\end{tabular}

beberapa penelitian terkait yang telah dilakukan sebelumnya yaitu sebagai berikut.

\begin{tabular}{|c|c|c|}
\hline & & $\begin{array}{c}\text { memanfaatkan } \\
\text { perhitungan } \\
\text { kompleksitas pada } \\
\text { tiap bit-plane dalam } \\
\text { menyelipkan } \\
\text { informasi rahasia. }\end{array}$ \\
\hline $\begin{array}{l}\text { [Kamdar } \\
\text { 2012] }\end{array}$ & $\begin{array}{c}\text { Lapisan Dual Data } \\
\text { Persembunyian } \\
\text { Menggunakan } \\
\text { Kriptografi Dan } \\
\text { Steganografi }\end{array}$ & $\begin{array}{l}\text { Hasil dari paket dari } \\
\text { kriptografi gambar } \\
\text { menggunakan kunci } \\
\text { publik. Gambar yang } \\
\text { dihasilkan dari } \\
\text { Steganografi } \\
\text { menggunakan } \\
\text { discrete cosine } \\
\text { transform (DCT) }\end{array}$ \\
\hline $\begin{array}{l}\text { [Shaik } \\
\text { 2012] }\end{array}$ & $\begin{array}{l}\text { Keamanan Data } \\
\text { dan Otentikasi } \\
\text { menggunakan } \\
\text { Steganografi dan } \\
\text { protokol STS }\end{array}$ & $\begin{array}{l}\text { Pendekatan yang } \\
\text { diusulkan dalam } \\
\text { makalah ini } \\
\text { menggunakan } \\
\text { pendekatan } \\
\text { steganografi yang } \\
\text { menyediakan } \\
\text { keamanan dan STS } \\
\text { protokol yang } \\
\text { menyediakan } \\
\text { otentikasi. } \\
\text { pengiriman berbagi } \\
\text { kunci rahasia } \\
\text { (stegokey) }\end{array}$ \\
\hline $\begin{array}{l}\text { [Shahana } \\
\text { 2013] }\end{array}$ & $\begin{array}{c}\text { Teknik } \\
\text { Peningkatan } \\
\text { Keamanan untuk } \\
\text { Steganografi } \\
\text { Menggunakan } \\
\text { DCT dan RSA }\end{array}$ & $\begin{array}{c}\text { Penelitian ini } \\
\text { merupakan } \\
\text { penggabungan } \\
\text { algoritma } \\
\text { Steganografi } \\
\text { berbasis DCT, Untuk } \\
\text { memberikan } \\
\text { keamanan yang } \\
\text { tinggi Steganografi } \\
\text { dan Kriptografi } \\
\text { digabungkan } \\
\text { bersama-sama }\end{array}$ \\
\hline
\end{tabular}


Penelitian-penelitian di atas memiliki tujuan yang sama dengan penelitian tesis ini yaitu pengamanan ganda pada pesan rahasia yang berupa text dengan menggunakan teknik Steganografi metode LSB dengan Algoritma Kriptografi. Namun perbedaan yang mendasar adalah bahwa penelitian tesis ini menggunakan teknik Kriptografi metode Vigenere Cipher sebagai fokus utama dalam penelitiannya.

\section{F. OBJEK PENELITIAN}

Pada penelitian ini obyek penelitian yang akan menjadi fokus dalam mengembangkan aplikasi ini adalah sebagai berikut:

\section{a. Laptop}

Perangkat laptop yang akan digunakan untuk implementasi aplikasi khususnya untuk proses pemrograman memiliki spesifikasi sebagai berikut:

1) Prosesor: Intel Core i3 @ 2,53 Ghz

2) Memori: $4 \mathrm{~GB}$
3) Hard disk: $283 \mathrm{~GB}$

4) Microsoft Windows 7 Professional 64 bit

\section{b. Komputer}

Perangkat komputer yang akan digunakan untuk implementasi aplikasi khususnya untuk proses pemrograman memiliki spesifikasi sebagai berikut:

1) Prosesor: AMD A4-5300 CPU 3.4Ghz

2) Memori: $2 \mathrm{~GB}$

3) Hard disk: $500 \mathrm{~GB}$

4) Microsoft Windows XP SP2 32 bit.

\section{c. Visual Basic .NET 2005}

Dengan menggunakan alat ini, para programmer dapat membangun aplikasi Windows Forms,

\section{G. POLA PIKIR}

Dalam melakukan penelitian ini, pola pikir yang akan digunakan guna menyelesaikan rumusan masalah penelitian dapat dilihat pada Gambar berikut ini.

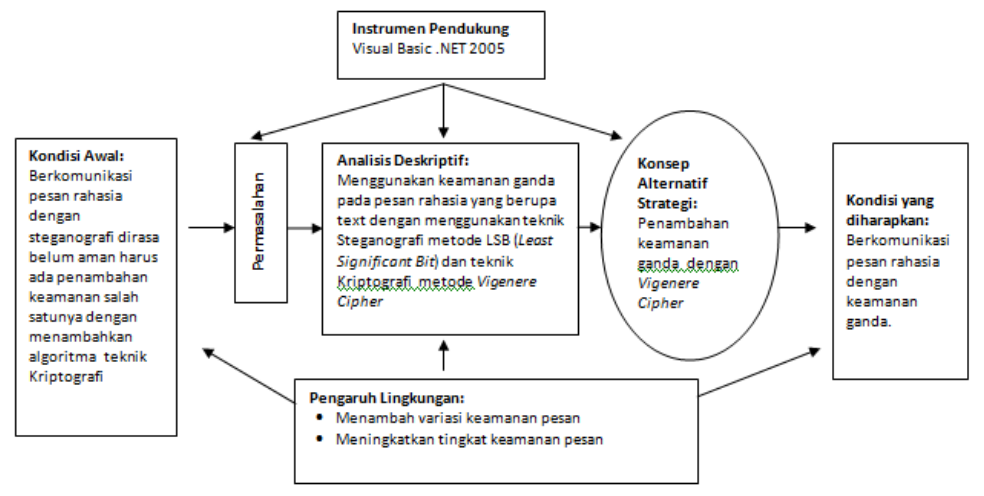

Gambar II : Ilustrasi Dasar Konsep Steganografi LSB

\section{III.DESIGN PENELITIAN}

\section{A. LANGKAH LANGKAH PENELITIAN}

Tahapan-tahapan yang dilakukan dalam rangka melakukan penelitian pengembangan aplikasi teknik pengamanan ganda pada pesan rahasia yang berupa text dengan menggunakan teknik Steganografi metode LSB (Least Significant Bit) dan teknik
Kriptografi metode Vigenere Cipher adalah sebagai berikut: 


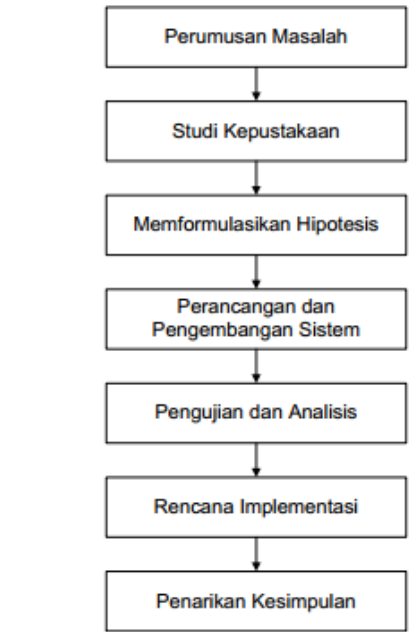

Gambar III: Langkah-langkah penelitian

\section{B. ALGORITMA SISTEM YANG \\ DIKEMBANGKAN}

Sistem yang dikembangkan memiliki algoritma encode dan decode. Algoritma encode sebagai berikut:

1. Tampil menu utama, dengan dua tombol pilihan, encode dan decode.

2. Pilihan encode akan menyisipkan pesan rahasia, akan tampil dua buah tombol untuk memilih cover-image, apakah dari kamera dengan memotret, atau dengan memilih citra yang sudah ada di galeri.

3. Setelah citra sudah ada, pesan rahasia diminta diketik untuk nantinya disisipkan ke dalam citra.

4. Memilih cara untuk mengirimkan stegoimage.

Sedangkan algoritma decode adalah sebagai berikut:

1. Tampil menu utama, dengan dua tombol pilihan, encode dan decode.

2. Pilihan decode akan mengambil pesan rahasia dari stego-image.

3. Memilih stego-image dari media penyimpanan yang ada di dalam perangkat.

4. Stego-image di-decode, lalu tampil pesan rahasia.

\section{FLOWCHART SISTEM YANG \\ DIKEMBANGKAN}

Alur diagram atau flowchart dari sistem yang dikembangkan adalah sebagai berikut:

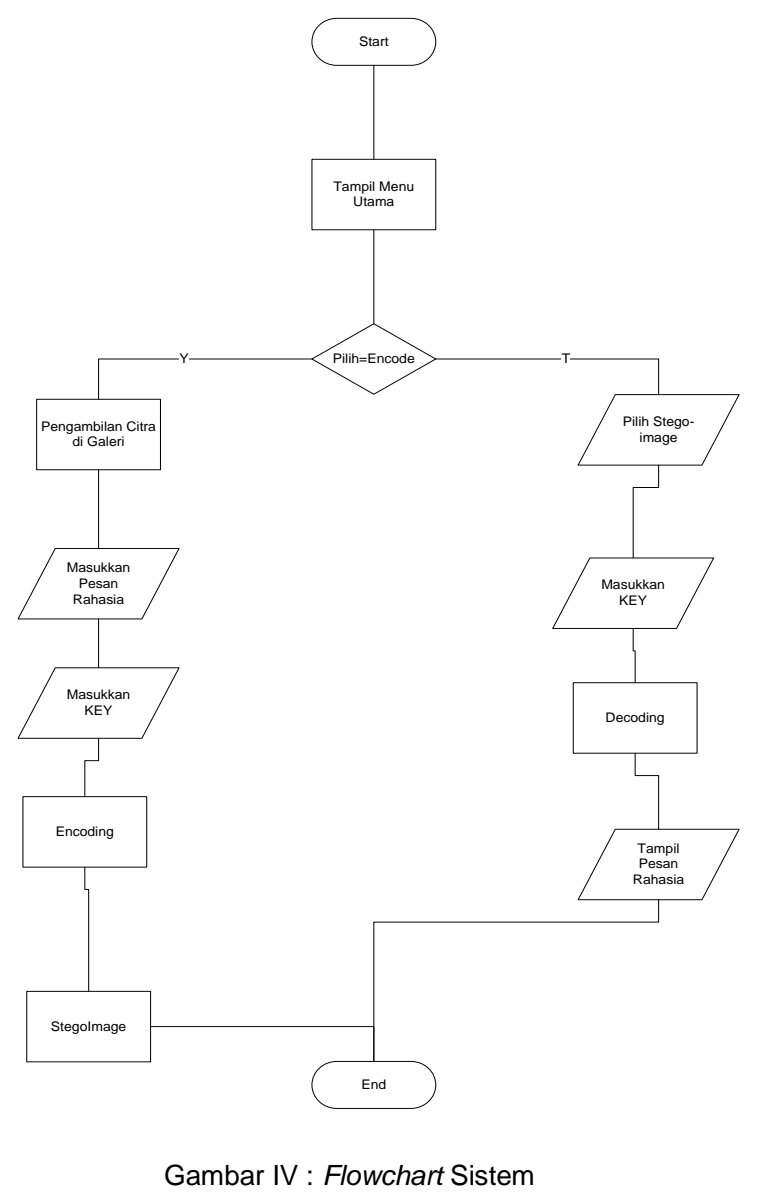

D. PENGUJIAN DAN ANALISIS

Proses pengujian dan analisis dilakukan untuk mengidentifikasi apakah sistem yang dikembangkan sesuai dengan analisis sistem yang telah dibuat. Pengujian sistem yang dilakukan dengan pengujian ISO 9126, black box serta PSNR dan MSE. Pegnujian ISO 9126 mengidentifikasi enam karakteristik kualitas perangkat lunak utama yaitu: Functionality, Reliability, Usability, Efficiency, Maintainability, Portability. Untuk syarat pengujian dapat digunakan minimal empat karakteristik sebagai acuan dasar. Pengujian black box dilakukan dengan menjalankan atau mengeksekusi unit atau modul, kemudian diamati apakah hasil dari unit tersebut sesuai dengan proses yang 
diinginkan atau tidak. Pengujian Analisis Data PSNR dan MSE pada image cover-image dan stego-image untuk melihat perubahan kulitas gambar yang dihasilkan dan dinyatakan layak digunakan.

Dari hasil pengujian tersebut selanjutnya akan dianalisis berdasarkan hipotesis yang telah diformulasikan untuk ditarik kesimpulan.

\section{IV.PEMBAHASAN DAN HASIL PENELITIAN}

\section{A. ANALISIS SISTEM}

Pada tahap analisis sistem aplikasi menggunakan teknik Steganografi metode LSB (Least Significant Bit) dan teknik Kriptografi metode Vigenere Cipher ini menggunakan pendekatan desain dan analisis berorientasi objek atau Object Oriented Analysis and Design (OOAD) dengan menggunakan notasi Unified Modeling Language (UML).

\section{a) Actor}

Actor pada aplikasi terbagi menjadi dua, yaitu pengirim dan penerima yang masingmasing memiliki tugas sebagai berikut.

Pengirim: Orang yang menggunakan aplikasi untuk mengirimkan pesan rahasia kepada penerima berupa Stegolmage.

Penerima: Orang yang menggunakan aplikasi untuk membaca pesan rahasia didalam Stegolmage yang dikirimkan oleh pengirim.

\section{b) Use Case}

Dalam rangka memberikan gambaran yang jelas terhadap use case aplikasi ini, maka use case diagram yang dibuat dibagi menjadi 2 yaitu Encode Stegano and kripto message use case diagram, dan decode Stegano and kripto message use case diagram. Secara detil setiap use case diagram aplikasi ini akan dijelaskan sebagai berikut.

\section{a. Encode Stegano and kripto message use case diagram}

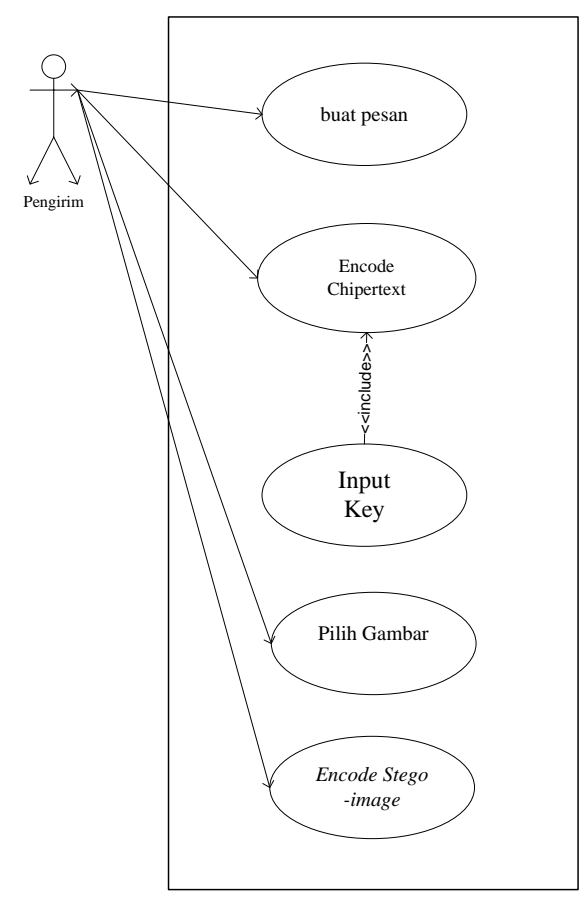

Gambar V : Encode Stegano and kripto message

Use case diagram di atas menggambarkan interaksi antara actor, yaitu pengirim pesan dengan sistem. Sedangkan use case terdiri dari enam yaitu: membuat pesan berupa plaintext, Memasukkan KEY, encode plaintext menajdi chipertext pada proses kriptografi, membuat cover image, encode chipertext menjadi stego-image pada proses steganografi, share stego-image.

\section{b. Decode Stegano and kripto message use case diagram}




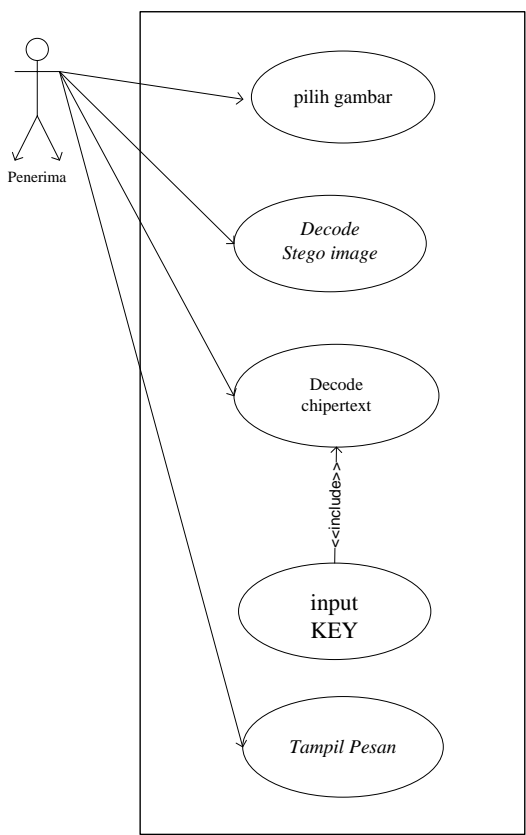

Gambar VI : Decode Stegano and kripto message

Use case diagram di atas menggambarkan interaksi antara actor, yaitu penerima pesan dengan sistem. Sedangkan use case di dalam aplikasi ini dibagi tiga yaitu: mengambil stego-image, decode stego image dan keluarkan chipertext, Masukkan KEY, decode chipertext menjadi plaintext, tampilkan pesan rahasia.

c) Activity Diagram

Activity diagram dibuat berdasarkan sebuah atau beberapa use case pada use case diagram. Activity diagram menggambarkan berbagai alur aktivitas dalam sebuah sistem yang sedang dirancang, bagaimana masing-masing alur memulai aktivitas, keputusan apa yang mungkin terjadi dan bagaimana aktivitas berakhir. Secara umum activity diagram untuk aplikasi pengamanan pesan rahasia menggunakan teknik Steganografi metode LSB (Least Significant Bit) dan teknik Kriptografi metode Vigenere Cipher berbasis VB.NET dapat dilihat pada Gambar di bawah ini.
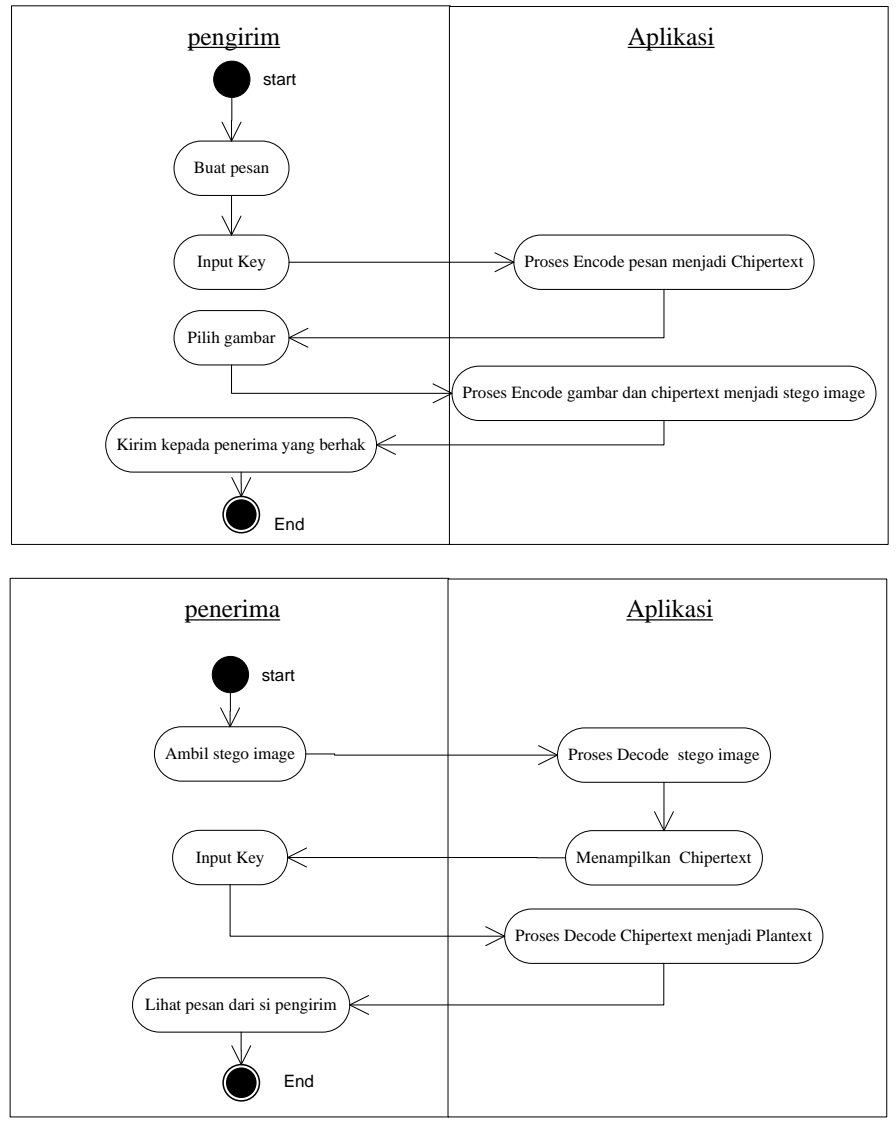

Gambar VII : Activity diagram

\section{d) Sequence diagram}

Sequence diagram tersebut menggambarkan interaksi antar obyek dan mengindikasikan komunikasi di antara obyekobyek tersebut. Obyek-obyek tersebut kemudian diurutkan dari kiri ke kanan dimana actor yang menginisiasi interaksi diletakkan di paling kiri dari sequence diagram. 


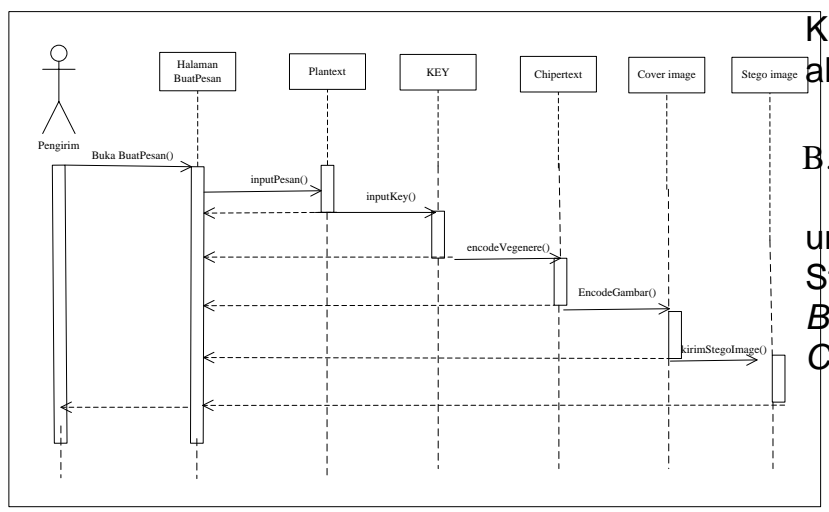

Gambar VIII: Sequence diagram pengirim aplikasi pesan rahasia

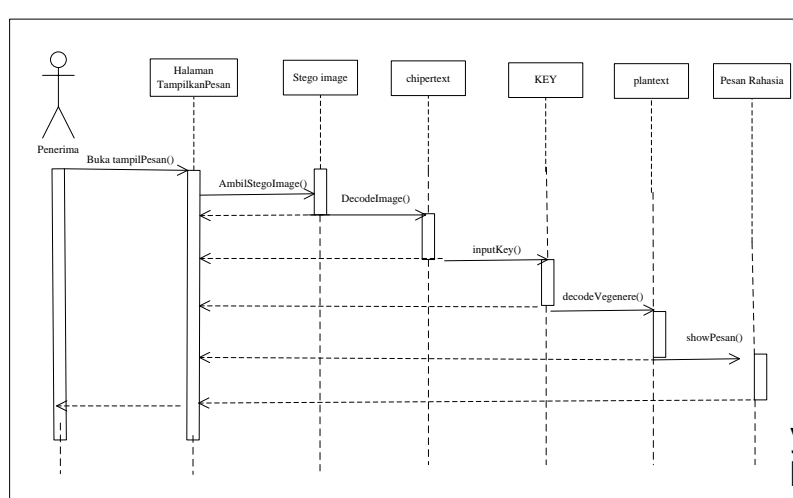

Gambar IX: Sequence diagram penerima aplikasi pesan rahasia

di atas merupakan sequence diagram dari aplikasi pengamanan pesan rahasia menggunakan teknik Steganografi metode LSB (Least Significant Bit) dan teknik
Kriptografi metode Vigenere Cipher yang akan dikembangkan.

B. PERANCANGAN LAYAR APLIKASI

Berikut ini adalah GUI yang dirancang untuk aplikasi pesan rahasia teknik Steganografi metode LSB (Least Significant Bit) dan teknik Kriptografi metode Vigenere Cipher berbasis VB.NET.

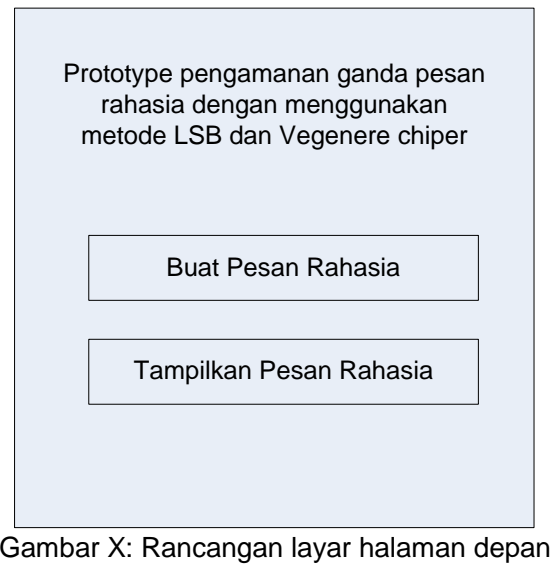

Ketika aplikasi dijalankan, pertama kali yang muncul adalah halaman utama yang berisi menu pilihan. Ada pilihan "Buat pesan Rahasia" dan "Tampilkan Pesan Rahasia". Bila pengirim ingin mengirimkan pesan rahasia, maka ia harus memilih "Buat pesan Rahasia" untuk memulainya. 


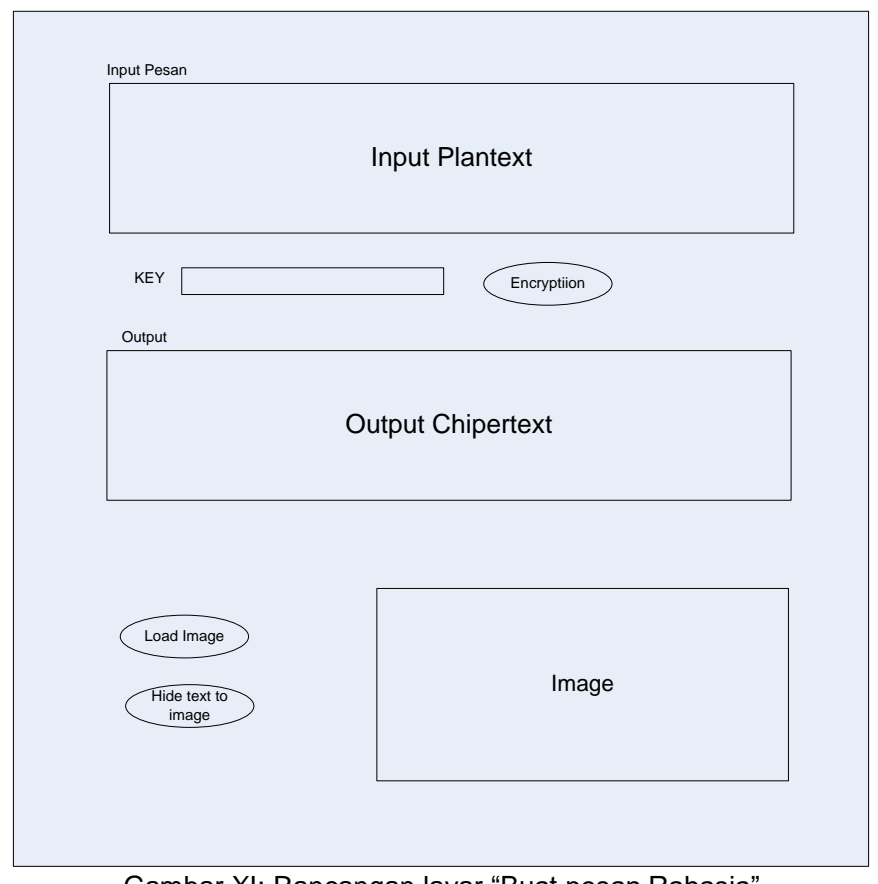

Gambar XI: Rancangan layar "Buat pesan Rahasia"

Disini pengirim akan membuat pesan rahasia menjadi pesan yang bisa dimengerti (plaintext) menjadi pesan yang tidak bisa dimengerti (chiperter) menggunakan teknik vigenere chiper dan kemudian pengirim mengambil cover-image yang dia miliki Lalu secara otomatis sistem akan memasukkan chipertext yang telah ada kedalam cover image untuk diproses melalui teknik LSB menjadi sebuah stego image. Stego image yang dihasilkan bisa langsung disebarluaskan atau share melalui berbagai media seperti: email, Social Media, sharing file, dan lain-lain.

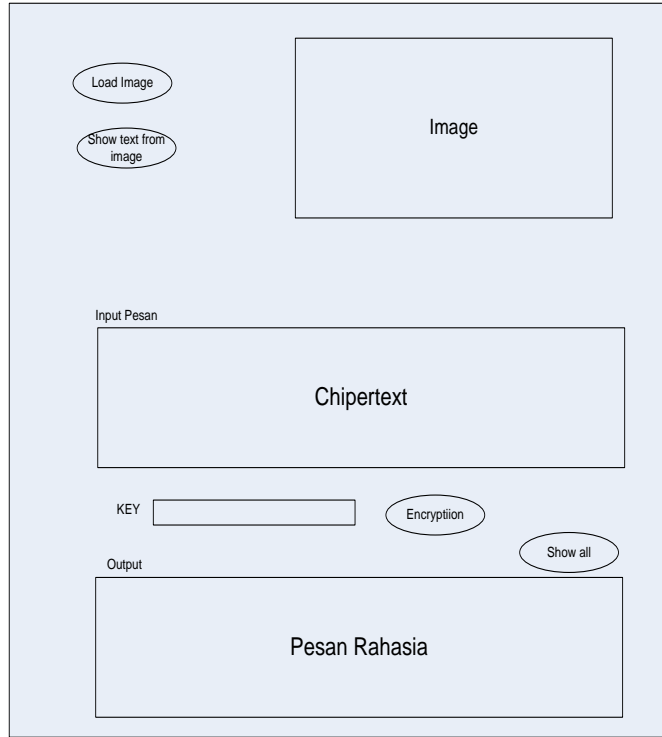

Gambar XII : Rancangan layar "Tampilkan Pesan Rahasia"

Penerima diminta untuk memasukkan stego-image yang telah ia terima. Setelah itu barulah tekan tombol show text from image seperti pada tampilan gambar diatas. Setelah itu akan muncul pesan rahasia yang masih bersifat chipertext sehingga belum bisa dipahami dengan jelas isi dari pesan yang ditampilkan. Untuk menampilkan pesan rahasia yang sesungguhnya pengguna atau 
penerima harus mengetahu KEY yang dimasukkan sebelumnya oleh si pembuat pesan. Setelah itu barulah si penerima pesan dapat membaca pesan rahasia yang dimaksud.

\section{IMPLEMENTASI PROGRAM}

Pada tahap implementasi program akan dilakukan penerjemahan setiap use case yang terdapat pada analisis sistem dengan menggunakan bahasa pemrograman VB.NET menjadi bentuk method yang dimengerti oleh perangkat komputer untuk mengeksekusi suatu proses.

a) Halaman Utama

Ketika aplikasi steganografi ini dijalankan, maka yang akan muncul pertama kali adalah halaman utama. Pada halaman utama ini ada dua buah tombol yang berisi pilihan "Buat pesan Rahasia" dan "Tampilkan Pesan Rahasia".

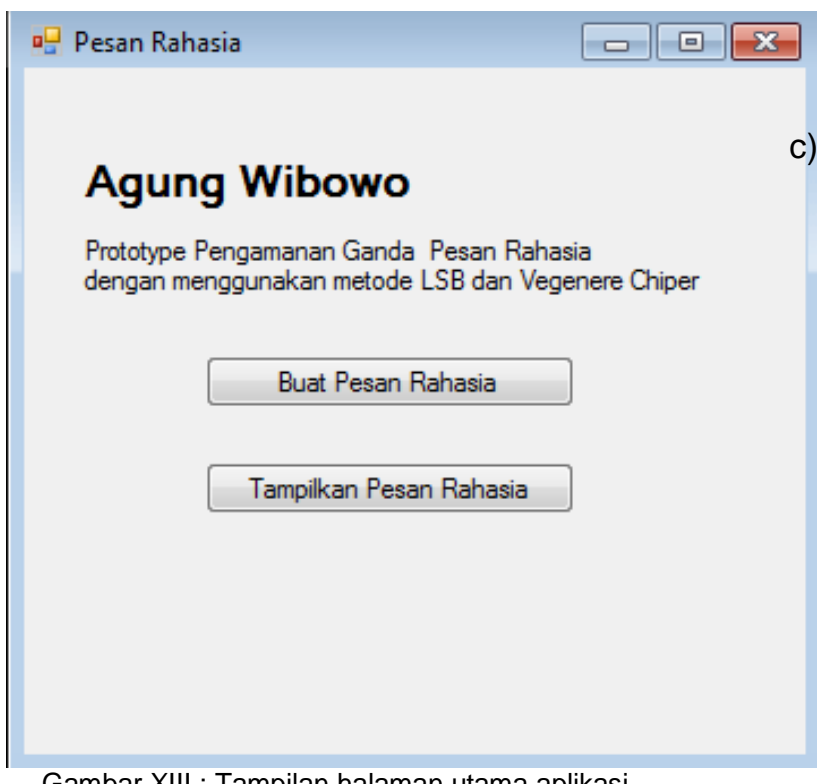

Gambar XIII : Tampilan halaman utama aplikasi

b) Halaman "Buat Pesan Rahasia"

Pada proses ini ada pembuatan pesan dari bentuk plaintext ke dalam bentuk chipertext dan dilanjutkan pengambilan citra yang akan digunakan untuk disisipi pesan, cover-image menjadi stego-image dengan menggunakan Proses penggabungan teknik Steganografi metode LSB (Least Significant Bit) dan teknik Kriptografi metode Vigenere Cipher, dan setelah stego-image berhasil dibuat penggna dapat menyebarluaskan hasilnya melalui berbagai media.

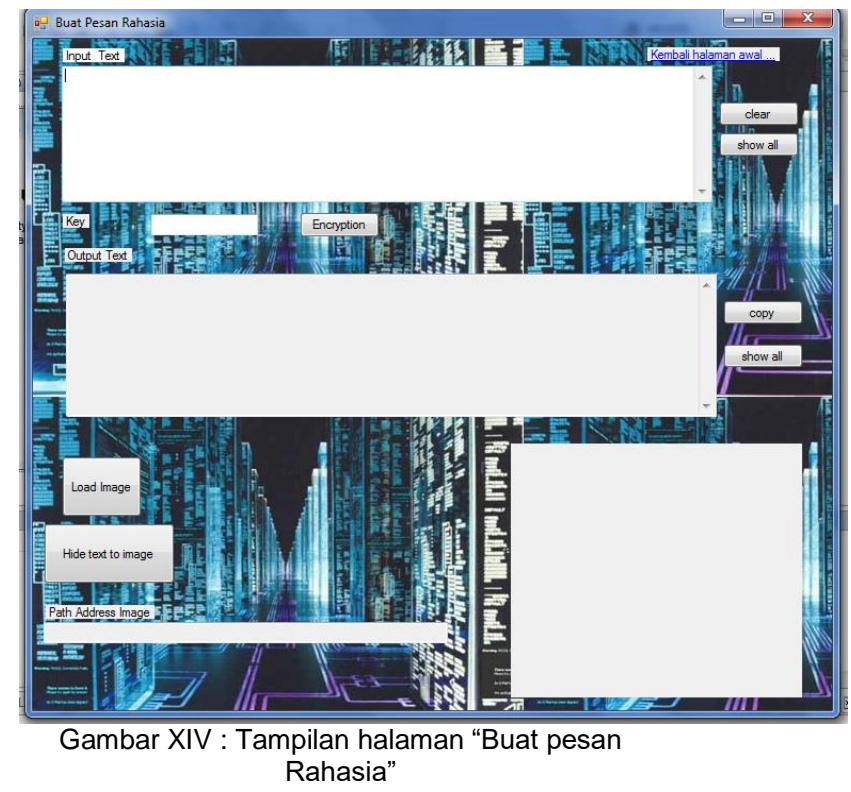

c) Halaman "Tampilkan Pesan Rahasia"

Pada proses ini pengambilan stegoimage media penyimpanan perangkat, lalu stego-image tersebut di-decode hingga ditampilkan isi pesan rahasianya.

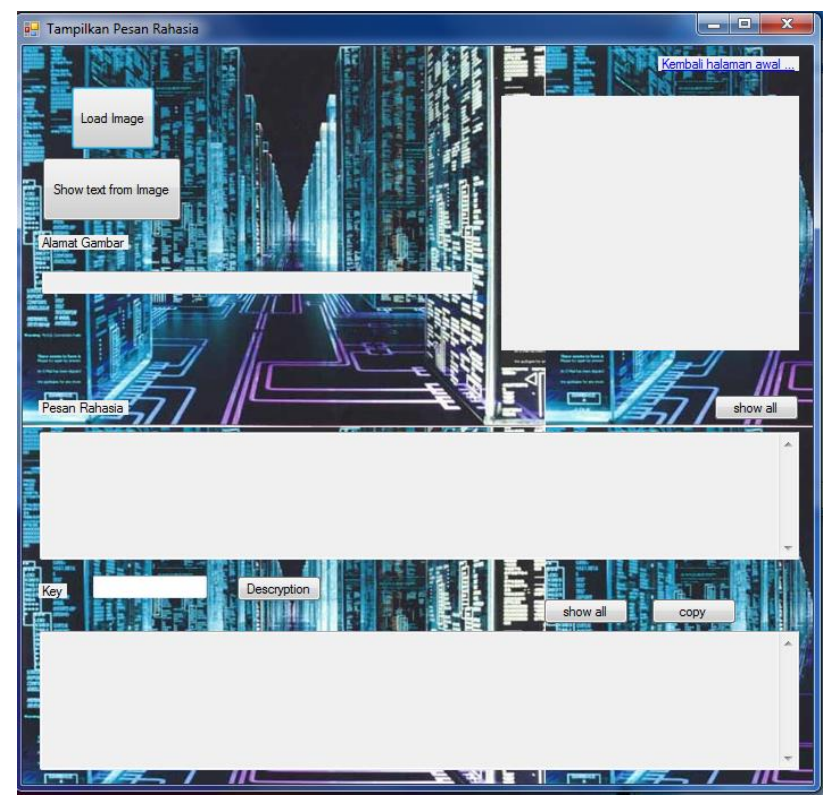




\section{Gambar XV : Tampilan halaman "Tampilkan Pesan Rahasia"}

Selanjutnya jika pesan telah ditampilkan pengguna dapat memanfaatkan tampilan lebih lebar dengan menekan tombol fungsi "show all" yang menghasilkan tampilan lebih lebar dan nyaman untuk membaca isi pesan rahasia tersebut.

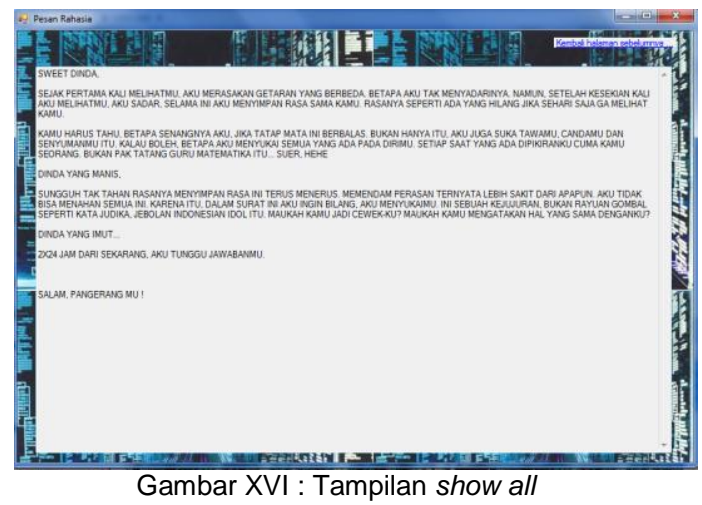

Ketika tombol fungsi show all di aktifkan maka seluruh pesan rahasia langsung dimunculkan di layar seperti gambar diatas.

\section{PENGUJIAN SISTEM}

Pengujian sistem yang dilakukan adalah pengujian black box dan pengujian PSNR (peak signal to noise rasio) dan MSE (mean square error) dan pengujian dengan pengujian ISO 9126.

\section{a) Pengujian Black Box}

Proses yang dijadikan objek pada pengujian black box ini terdiri proses encode metode vigenere chiper, encode metode LSB, decode metode vigenere chiper dan proses decode metode LSB.

\section{a. Pengujian proses encode metode vigenere chiper.}

\section{Table II : encode metode vigenere chipper}

\begin{tabular}{|c|c|}
\hline Skenario & Yang Diharapkan \\
\hline
\end{tabular}

\begin{tabular}{|c|c|}
\hline $\begin{array}{c}\text { Input pesan plaintext dan } \\
\text { masukkan pula KEY } \\
\text { sebagai syarat methode } \\
\text { vigenere chiper }\end{array}$ & $\begin{array}{l}\text { Pesan plaintext berhasil } \\
\text { dirubah menjadi chipertext } \\
\text { vigenere chiper sesuai } \\
\text { dengan KEY yang } \\
\text { dimasukkan }\end{array}$ \\
\hline $\begin{array}{c}\text { Tekan tombol clear yang } \\
\text { ada pada input pesan }\end{array}$ & $\begin{array}{l}\text { Form pengisian pesan yang } \\
\text { sudah dimasukkan kembali } \\
\text { kosong }\end{array}$ \\
\hline $\begin{array}{c}\text { Tekan tombol show all } \\
\text { yang ada pada input } \\
\text { pesan }\end{array}$ & $\begin{array}{l}\text { Isi pesan dapat ditampikan } \\
\text { secara lebih luas sehingga } \\
\text { mudah untuk dibaca }\end{array}$ \\
\hline $\begin{array}{l}\text { Masukkan KEY yang } \\
\text { berbeda lalu lakukan } \\
\text { prose encode vigenere } \\
\text { chiper }\end{array}$ & $\begin{array}{l}\text { Pesan chipertext dapat } \\
\text { berubah ubah tidak statis } \\
\text { menyesuikan KEY yang } \\
\text { dimasukkan sebelumnya, } \\
\text { sehingga lebih sulit untuk } \\
\text { ditebak. }\end{array}$ \\
\hline $\begin{array}{l}\text { Tekan tombol copy yang } \\
\text { ada pada tampilan pesan } \\
\text { rahasia yang sudah } \\
\text { dirubah menjadi pesan } \\
\text { chipertext }\end{array}$ & $\begin{array}{l}\text { Isi pesan dapat di copy } \\
\text { seluruhnya sehingga lebih } \\
\text { memudahkan pengguna. }\end{array}$ \\
\hline
\end{tabular}

\section{b. Pengujian proses encode metode} LSB.

Table III : encode metode $L S B$

\begin{tabular}{|c|c|}
\hline Skenario & Yang Diharapkan \\
\hline $\begin{array}{c}\text { Ambil gambar cover- } \\
\text { image format JPG dan } \\
\text { masukkan pesan } \\
\text { chipertext kedalam } \\
\text { gambar dengan LSB }\end{array}$ & $\begin{array}{c}\text { Gambar cover-image } \\
\text { disisipkan pesan } \\
\text { chipertext dan } \\
\text { menghasilkan stego- } \\
\text { image berformat JPG }\end{array}$ \\
\hline Ambil gambar cover- & Gambar cover-image \\
\hline
\end{tabular}




\begin{tabular}{|c|c|}
\hline $\begin{array}{c}\text { image format Glf dan } \\
\text { masukkan pesan } \\
\text { chipertext kedalam } \\
\text { gambar dengan LSB }\end{array}$ & $\begin{array}{c}\text { disisipkan pesan } \\
\text { chipertext dan } \\
\text { menghasilkan stego- } \\
\text { image berformat Gif }\end{array}$ \\
\hline Ambil gambar cover- & Gambar cover-image \\
image format BMP & disisipkan pesan \\
dan masukkan pesan & chipertext dan \\
chipertext kedalam & menghasilkan stego- \\
gambar dengan LSB & image berformat BMP \\
& \\
\hline
\end{tabular}

c. Pengujian proses decode metode LSB.

Table IV : decode metode LSB

\begin{tabular}{|c|c|}
\hline Skenarion & Yang Diharapkan \\
\hline $\begin{array}{l}\text { Ambil gambar stego-image } \\
\text { format JPG dan keluarkan } \\
\text { isi pesan yang ada } \\
\text { didalmnya dengan proses } \\
\text { decode metode LSB }\end{array}$ & $\begin{array}{l}\text { Pesan chipertext yang } \\
\text { ada dalam stego- } \\
\text { image dapat di } \\
\text { keluarkan dan } \\
\text { ditampilkan dengan } \\
\text { proses decode } \\
\text { metode LSB }\end{array}$ \\
\hline $\begin{array}{l}\text { Ambil gambar stego-image } \\
\text { format Gif dan keluarkan } \\
\text { isi pesan yang ada } \\
\text { didalmnya dengan proses } \\
\text { decode metode LSB }\end{array}$ & $\begin{array}{l}\text { Pesan chipertext yang } \\
\text { ada dalam stego- } \\
\text { image dapat di } \\
\text { keluarkan dan } \\
\text { ditampilkan dengan } \\
\text { proses decode } \\
\text { metode LSB }\end{array}$ \\
\hline $\begin{array}{l}\text { Ambil gambar stego-image } \\
\text { format BMP dan keluarkan } \\
\text { isi pesan yang ada } \\
\text { didalmnya dengan proses } \\
\text { decode metode LSB }\end{array}$ & $\begin{array}{l}\text { Pesan chipertext yang } \\
\text { ada dalam stego- } \\
\text { image dapat di } \\
\text { keluarkan dan } \\
\text { ditampilkan dengan } \\
\text { proses decode } \\
\text { metode LSB }\end{array}$ \\
\hline
\end{tabular}

\section{d. Pengujian proses decode metode vigenere chiper.}

Table V : decode metode vigenere chiper.

\begin{tabular}{|c|c|}
\hline Skenario & Yang Diharapkan \\
\hline $\begin{array}{c}\text { Rubah chipertext yang ada } \\
\text { untuk dikembalikan menjadi } \\
\text { plaintext }\end{array}$ & $\begin{array}{c}\text { Pesan chipertext bisa dirubah } \\
\text { kembali menjadi plaintext } \\
\text { sehingga bisa dibaca isi dari } \\
\text { pesan rahasia didalamnya }\end{array}$ \\
\hline $\begin{array}{c}\text { Masukkan KEY yang salah dan } \\
\text { Rubah chipertext yang ada } \\
\text { untuk dikembalikan menjadi } \\
\text { plaintext }\end{array}$ & $\begin{array}{c}\text { Pesan chipertext bisa dirubah } \\
\text { kembali menjadi plaintext tetapi } \\
\text { tidak bisa dibaca isi dari pesan } \\
\text { rahasia didalamnya }\end{array}$ \\
$\begin{array}{c}\text { Tekan tombol show all yang ada } \\
\text { pada tampilan pesan rahasia } \\
\text { yang sudah kembali menjadi } \\
\text { plaintext }\end{array}$ & $\begin{array}{c}\text { Isi pesan dapat ditampikan } \\
\text { secara lebih luas sehingga } \\
\text { mudah untuk dibaca }\end{array}$ \\
\hline $\begin{array}{l}\text { Tekan tombol copy yang ada } \\
\text { pada tampilan pesan rahasia } \\
\text { yang sudah kembali menjadi } \\
\text { plaintext }\end{array}$ & $\begin{array}{c}\text { Isi pesan dapat di copy } \\
\text { seluruhnya sehingga lebih } \\
\text { memudahkan pengguna. }\end{array}$ \\
\hline
\end{tabular}

Berdasarkan hasil pengujian black box dapat disimpulkan bahwa sistem yang dikembangkan dapat mengetahui fungsifungsi yang salah atau hilang, kesalahan kinerja, inisialisasi dan secara fungsional mengeluarkan hasil yang sesuai dengan yang diharapkan.

b) Pengujian PSNR dan MSE

Proses yang dilakukan adalah dengan menggunakan 10 gambar cover-image berformat BMP dengan menyisipkan jumlah plaintext yang beragam. Data yang dihasilkan dimasukkan kedalam table. Aspek yang dicari adalah untuk menentukan perbandingan PSNR dan MSE dari masing-masing coverimage dan stego-image.

Table VI : Pengujian PSNR dan MSE

\begin{tabular}{|c|c|c|c|c|c|}
\hline no & Cover image & Stego image & $\begin{array}{c}\text { Total } \\
\text { char }\end{array}$ & MSE & PSNR \\
\hline 1 & sampel_1.bmp & sampel_1_stego.bmp & 1000 & 0 & 99.0000 \\
\hline 2 & sampel_2.bmp & sampel_2_stego.bmp & 2000 & 0.0013 & 87.6069 \\
\hline 3 & sampel_3.bmp & sampel_3_stego.bmp & 3000 & 0.0097 & 85.7863 \\
\hline
\end{tabular}




\begin{tabular}{|c|c|c|c|c|c|}
\hline 4 & sampel_4.bmp & sampel_4_stego.bmp & 4000 & 0.0121 & 80.3142 \\
\hline 5 & sampel_5.bmp & sampel_5_stego.bmp & 5000 & 0.0153 & 78.1298 \\
\hline 6 & sampel_6.bmp & sampel_6_stego.bmp & 6000 & 0.0212 & 76.1764 \\
\hline 7 & sampel_7.bmp & sampel_7_stego.bmp & 7000 & 0.0321 & 74.6011 \\
\hline 8 & sampel_8.bmp & sampel_8_stego.bmp & 8000 & 0.0532 & 70.2138 \\
\hline 9 & sampel_9.bmp & sampel_9_stego.bmp & 9000 & 0.0746 & 59.4039 \\
\hline 10 & sampel_10.bmp & sampel_10_stego.bmp & 10000 & 0.1624 & 64.6241 \\
\hline
\end{tabular}

Perbandingan MSE dan SNR dapat kita kita melalui grafik berikut :
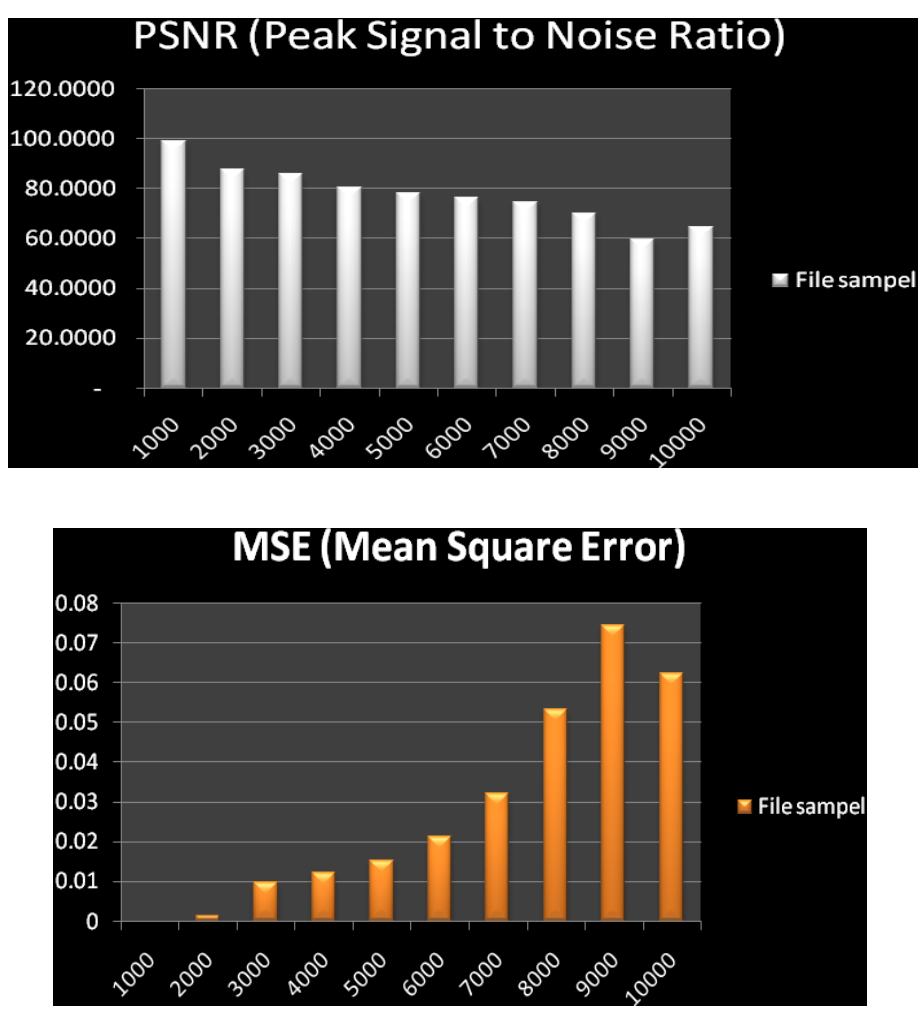

Gambar XVII: Tampilan chart diagram PSNR dan MSE

Dari grafik tersebut terlihat bahwa hasil penyisipan mengeluarkan stego-image yang memiliki kualitas baik pada nilai PSNR tinggi dengan nilai rata-rata 80 hingga jika kapasitas jumlah karakter semakin besar akan menurun dan nilai MSE rendah dengan nilai rata rata 0.03 hingga jika kapasitas jumlah karakter semakin besar akan naik.

\section{C) Pengujian ISO 9126}

Pengujian dilakukan dengan kuesioner dengan menggunakan 4 kriteria yaitu:

Table VII : Pengujian ISO 9126

\begin{tabular}{|l|l|l|l|l|}
\hline Aspek & Skor & Skor & $\%$ skor & kriteria \\
\hline
\end{tabular}

\begin{tabular}{|l|l|l|l|l|}
\hline & $\begin{array}{l}\text { Aktu } \\
\text { al }\end{array}$ & Ideal & aktual & \\
\hline $\begin{array}{l}\text { Functiona } \\
\text { lity }\end{array}$ & 153 & 180 & $85 \%$ & Sangat baik \\
\hline Reliability & 137 & 150 & $91 \%$ & Sangat baik \\
\hline Usability & 168 & 180 & $93 \%$ & Sangat baik \\
\hline Efficiency & 53 & 60 & $88 \%$ & Sangat baik \\
\hline Total & $\mathbf{5 1 1}$ & $\mathbf{5 7 0}$ & $\mathbf{8 9 . 6 5 \%}$ & Sangat baik \\
\hline
\end{tabular}

$\%$ Skor aktual $=\underline{\text { Skor Aktual }} \times 100 \%$

Skor Ideal

$=\underline{511} \times 100 \%=89.65 \%$ (kriteria sangat baik) 570 
Berdasarkan keseluruhan tabel diatas dapat disimpulkan bahwa tingkat kualitas prototype aplikasi secara keseluruhan dalam kriteria sangat baik dengan persentase $89.65 \%$ kriteria sangat baik.

\section{PENUTUP}

\section{A. KESIMPULAN}

Penelitian penggunaan aplikasi pengamanan ganda pesan rahasia menggunakan teknik Steganografi metode LSB (Least Significant Bit) dan teknik Kriptografi metode Vigenere Cipher berbasis VB.NET. Setelah dilakukannya pengujian fungsi-fungsi aplikasi secara Black Box dan pengujian kualitas gambar yang dihasilkan baik secara PSNR dan MSE aplikasi prototype pesan rahasia menggunakan teknik Steganografi metode LSB (Least Significant Bit) dan teknik Kriptografi metode Vigenere Cipher. dan pengujian dengan pengujian ISO 9126. Secara umum bisa dinyatakan layak untuk diimplementasikan dan untuk digunakan oleh masyarakat umum.

\section{B. SARAN}

Dari penelitian ini masih memiliki kekurangan dan memerlukan penelitian lanjutan guna menyempurnakannya. Beberapa hal yang perlu penelitian lanjutan yaitu sebagai berikut:

a) Penelitian dapat dilanjutkan dengan meningkatkan keamanan dengan menerapkan metode pengamanan ganda yang lebih kompleks dari penggabungan teknik Steganografi metode LSB (Least Significant Bit) dan teknik Kriptografi metode Vigenere Cipher.

b) Penelitian dapat dilanjutkan dengan meningkatkan keamanan melalui penambahan login untuk menjalankan aplikasi ini.

c) Penelitian dapat dilanjutkan dengan menambahkan kemampuan aplikasi untuk dapat menyisipkan pesan rahasia pada media lain seperti suara, video dan file berformat lainnya.

d) Aplikasi dapat diimplementasikan juga pada aplikasi mobile seperti iOS, Android ataupun Windows Phone. diharapkan dapat lebih memudahkan pengguna. e) Semakin banyak penelitian yang dilakukan, terutama yang berhubungan dengan keamanan pesan rahasia yang di lakukan secara berlapis, diharapkan dapat terus meningkatkan variasi-variasi teknik kemanan yang ada sekarang ini dan memberikan rasa aman yang lebih baik kedepannya

\section{REFERENSI}

[1] A. J Menezes, P. van Oorschot and S. Vanstone - Handbook of Applied Cryptography UK: CRC Press.

[2] Ariyus, Dony, Kriptografi - Keamanan Data Dan Komunikasi, Graha Ilmu, Yogyakarta, 2006.

[3] Ariyus, Dony, Pengantar IImu Kriptografi: Teori, Analisis, dan Implementasi. Penerbit Andi, Yogyakarta, 2008.

[4] Alatas, Putri, Implementasi Teknik Steganografi dengan Metode LSB pada Citra Digital, Universitas Gunadarma, Jakarta, 2009.

[5] B.Tjaru, Setia Negara, Modifikasi Full Vigenere Chipher dengan Pengacakan Susunan Huruf pada Bujur Sangkar Berdasarkan Kunci, ITB Bandung, 2012.

[7] G. Kamdar, Dolly Patira, Dr. C. H. Vithalani, Dual Layer Data Hiding Using Cryptography And Steganography, International Journal of Scientific Engineering and Technology (ISSN : 2277-1581) www.ijset.com, Volume No.1, Issue No.4, pg :134-138, Oktober 2012

[8] Leonardo, Kevin Handoyo, Modifikasi Vigenere Cipher dengan Metode Penyisipan Kunci pada Plaintext, ITB, Bandung, 2012.

[9] A. P. Petitcolas, R. J. Anderson, and M. G. Kuhn, Information Hiding -A Survey, 
Proceeding of the IEEE, vol. 87, Issue 7, pp. 1062-1078, Juli 1999.

[10] Prasetyo, Bambang dan Jannah, L.M., Metode Penelitian Kuantitatif, Jakarta: PT. Rajagrafindo Persada, 2005.

[11] Ramadhani, Budi, Steganografi pada Citra GIF mengggunakan bahasa pemrograman Delphi, UII, Yogyakarta, 2006.

[12] Rosziati Ibrahim and Law Chia Kee, MoBiSiS: An-Android based Application for Sending Stego Image through MMS, ICCGI 2012 : The Seventh International Multi-Conference on Computing in the Global Information Technology, 2012.

[13] Esti Suryani,Titin sri Martini, Kombinasi Kriptografi dengan Hillchipher dan staganografi dengan LSB untuk keamanan data text, Universitas Muhammadiyah, Magelang.

[14] Sulidar Fitri, Implementasi Algoritma Kriptografi DES dan Watermark dengan Metode LSB pada data Citra, Universitas AMIKOM, Yogyakarta, 2010.

[15] Suranta, Ricardo Pramana, Perbandingan Ketahanan Algoritma LSB dan F5 dalam Steganografi Citra, ITB, Bandung, 2012
[16] Sugiyono, Metode Penelitian Kuantitatif, Kualitatif dan $R \& D$, Bandung: Alfabeta, 2012.

[18] Shrikant S. Khaire and Dr. Sanjay L. Nalbalwar, Review: Steganography Bit Plane Complexity Segmentation (BPCS) Technique, International Journal of Engineering Science and Technology, Vol. 2(9), 4860-4868, 2010.

[19] Shahana T, An Enhanced Security Technique for Steganography Using $D C T$ and RSA, International Journal of Advanced Research in Computer Science and Software Engineering, Vol 3 , Issue 7 , July 2013

[20] Shaik Riyaz, J. Rajakala and M RamaKrishna, Data Security and Authentication using Steganography and STS protocol, International Journal of Advanced Research in Computer Science and Electronics Engineering, Volume 1, Issue 5, July 2012

[22] Namita Tiwari and Dr. Madhu Shandilya, Evaluation of Various LSB based Methods of Image Steganography on GIF File Format, International Journal of Computer Applications, vol. 6, September 2010.

[25] Triputra Safei, Timotius, Pengukuran dan Pengujian Kekuatan Algoritma Auto-key Vigenere Cipher, ITB, Bandung, 2012 